\title{
Saving Up for a Rainy Day? Savings Groups and Resilience to Flooding in Dar es Salaam, Tanzania
}

\author{
Alexandra Panman ${ }^{1}$ - Ian Madison ${ }^{2}$ - Nyambiri Nanai Kimacha ${ }^{3}$. \\ Jean-Benoît Falisse ${ }^{4}$
}

Accepted: 21 April 2021 / Published online: 29 April 2021

(c) The Author(s) 2021

\begin{abstract}
This paper explores the role of savings groups in resilience to urban climate-related disasters. Savings groups are a rapidly growing phenomenon in Africa. They are decentralized, non-institutional groups that provide millions of people excluded from the formal banking sector with a trusted, accessible, and relatively simple source of microfinance. Yet there is little work on the impacts of savings groups on resilience to disasters. In this paper, we use a combination of quantitative and qualitative evidence from Dar es Salaam (Tanzania) to shed new light on the role that savings groups play in helping households cope with climate-related shocks. Drawing on new data, we show that approximately one-quarter of households have at least one member in a group, and that these households recover from flood events faster than those who do not. We further argue that the structure of savings groups allows for considerable group oversight, reducing the high costs of monitoring and sanctioning that often undermine cooperative engagement in urban areas. This makes the savings group model a uniquely flexible form of financing that is well adapted to helping households cope with shocks such as repeated flooding. In addition to this, we posit that they may provide a foundation for community initiatives focusing on preventative action.
\end{abstract}

Keywords Savings groups $\cdot$ Floods $\cdot$ Dar es Salaam $\cdot$ Resilience $\cdot$ Recovery financing $\cdot$ Disaster prevention

\section{Introduction}

Fatima was at work when flood waters swept away her young son. According to the Tanzania Meteorological Agency, the 2011 rains had been the heaviest since the country's independence in 1961. Across Dar es Salaam roads were inundated,

Alexandra Panman

a.panman@ucl.ac.uk

Extended author information available on the last page of the article 
bridges destroyed, and hundreds were left homeless. Over 5000 people were displaced and at least 43 lost their lives (Anande \& Luhunga, 2019). Thankfully, Fatima's son was not one of them. A neighbor had spotted the injured boy and quickly pulled him from the fetid water. Medical attention was crucial, but the hospital was far away. It was at this point that Fatima's neighbor drew upon a common resource for residents of Dar es Salaam. Fatima explained that her neighbor "was part of my savings group... [so] she was able to get emergency cash from our group to pay for a Bajaj [a three-wheeled motorcycle taxi] to the hospital. It saved my son's life."

All over the world, people like Fatima turn to their neighbors and friends when disaster strikes. Community members are often the first—and sometimes the only-responders. Adapting and recovering from climate-related shocks often rests on being able to draw on social networks, local engagement, and community identity and attachment (Elias-Trostmann et al., 2018). This is part of the idea of "community resilience" championed by international aid organizations and national governments as a key complement to existing efforts to strengthen top-down disaster management policies (Dickson et al., 2012; Global Disaster Preparedness Center, 2019; Gupte, 2019). While the boundaries and usefulness of the notion of "resilience" remain debated (Manyena, 2006), it remains clear that collective action can help people after disasters and can help address challenges that exacerbate flood risks. Yet collective action is not automatic. Among other things, it requires the capacity for people to monitor and sanction each other's behavior to prevent beneficiaries from free-riding (Fafchamps, 1992; Ostrom, 2005).

The literature describes collective action, coordination, and cooperation as more difficult in urban settings where social relations are typically more fragmented than in rural areas (Baland \& Platteau, 2000; Ellickson, 1991). Cities tend to be large, anonymous places, and urban residents frequently move. In Dar es Salaam, 57\% of households are renters who on average have lived in their current accommodation for less than 4 years (Panman \& Lozano-Gracia, 2021). Understanding bottom-up collective action in the face of disasters in this context is crucial for two reasons. First, urban dwellers in East Africa are among the most exposed populations to disaster risk in the world (Adelekan et al., 2015; IPCC, 2012), while the poor and women are particularly vulnerable (Neumayer \& Plümper, 2007; Simon, 2010). Second, rapid urbanization has left many governments on the back foot, unable to adequately react to disasters and adapt to risks in line with the pace of anthropogenic climate change.

In this paper we look at the role that savings groups play in helping people cope with the repeated risks of flooding. Savings groups were principally conceived as vehicles to increase financial inclusion and support entrepreneurship and employment (Smith \& Scott, 2015). However, studies have also begun to explore how savings group members are often drawn to groups as a means of dealing with emergencies (Beaman et al., 2014; Gash \& Odell, 2013; Jahns, 2014). In line with this literature, we posit that groups have a positive effect through two interconnected channels.

First, by providing access to emergency funds and encouraging people to save throughout the year, savings groups give households the financial means to react to flood damage. We find that member households are $12 \%$ more likely to have recovered from past flood events. Such households appear better able to smooth their consumption across the year by purchasing emergency supplies and investing in post-flood repairs without cutting back on vital expenditures (Gash \& Odell, 2013). 
Second, savings groups foster the social ties and engagement necessary for collective action during disasters. Many NGOs anticipate that savings groups can engender "social cohesion, solidarity, and mutual aid" (Allen \& Panetta, 2010, 12) or even "humility, trust, loyalty, assistance to the vulnerable, support for each other in times of need, and renewed belief in group activities by group members" (Odera \& Muruka, 2007 , v). Membership may also boost social capital in the community as it demonstrates a willingness for cooperation and sharing, giving members both social and economic advantages (Rodima-Taylor, 2012). We find evidence to support the assertion that group membership has a positive impact on these dynamics. Households with members in savings groups also tend to have larger social networks, and respondents often highlighted how their groups helped them expand and strengthen their social networks. We also find an indirect effect of belonging to a group. Savings groups are an effective means of providing financing for people living in highly precarious environments due to the ease with which members can monitor and sanction each other's behavior. The extensive knowledge group members have of each other's situations allows a degree of flexibility into lending practices that would not be sustainable in more formal institutional contexts, such as a bank or microcredit institution. For the same reason, we also argue that groups could potentially facilitate collective action for broader flood prevention activities.

To our knowledge, this is the first paper to look specifically at the relationship between savings group membership and resilience to urban flooding. In bringing together the literature on savings groups and urban resilience, this paper contributes new insights and raises new questions. We contribute to the literature on savings groups with data on the extent of group membership in one of Africa's fastest growing cities and insights on how these groups have evolved in the urban context. With respect to the literature on urban disaster resilience, we unpack the pathways linking group membership and resilience. The findings suggest that savings groups contribute to resilience in urban areas. However, further research is necessary to explore whether these informal, trust-based institutions can be successfully incorporated into urban resilience plans and actions.

This paper is structured as follows. Following this introduction, the "Background" section introduces the context and literature. After describing our methodology, the "Group Membership and Experience with Facing Floods" and "Savings Groups and Household Resilience to Flooding in Dar es Salaam" sections present our results on (1) the relationship between membership of savings groups and recovering from floods and (2) the savings group-level dynamics of solidarity and support in times of climaterelated disasters. The final section discusses the results against the broader debates in the field.

\section{Background}

With over 4.3 million inhabitants, Dar es Salaam is one of the largest cities in East Africa. Rapid urbanization has resulted in unplanned settlement in riverine and low-lying coastal areas, making significant areas of the city increasingly vulnerable to the effects of climate-related flooding (Collier \& Jones, 2017; World Bank, 2009). An estimated 10\% of Dar es Salaam's inhabitants face repeated 
direct impacts from floods, while another 39\% are exposed indirect effects such as lost work, missed school, or adverse impacts on health (Erman, 2019).

The Government of Tanzania, along with the UK Department for International Development and the World Bank, have recently embarked on a project to enhance resilience to climate related disasters in Dar es Salaam and across the country through the Tanzania Urban Resilience Program (TURP). This program aims to strengthen emergency response coordination, build new infrastructure to reduce exposure to flooding, and develop community-level plans for disaster response and risk reduction. In conjunction with TURP, the Tanzanian government's Disaster Management Act of 2015 established Disaster Management Committees at regional, district, ward, and sub-ward/village levels. At present, however, the lower -level councils only exist on paper due to the government's financial and capacity challenges. Similarly, under-resourced emergency services struggle to access many vulnerable communities due to poor infrastructure (Global Disaster Preparedness Center, 2019).

This leaves individual households as the main actors responsible for emergency preparedness and response. Tanzanians have long relied on diverse networks of mutual aid to help pool valued resources and cover the contingencies of life (Abrahams, 1985; Maghimbi, 1995, 2010; Ruel, 1959). These "economies of affection" based on reciprocal relations among individuals to achieve collective ends have deep roots in the country and across the region (Hyden, 1980), though the forms they have taken have evolved over time. A decisive moment for the shaping of the savings groups was the contraction of formal employment during the economic crisis of the 1980s and 1990s, the consequences of which led to the further proliferation of mutual aid groups such as rotating credit associations, burial societies, handicraft groups, informal work groups, and market women associations (for further information on the history of mutual aid in Tanznaia, see Rodima-Taylor, 2012). There is no official data on the current extent of membership of savings groups in Dar es Salaam. However, it is clear that the model has rapidly spread in recent years. By 2016, there were an estimated nine million participants in savings groups across Africa (le Polain et al., 2018).

Savings groups are a specific form of mutual aid. The model depends on regular, often weekly contributions from a self-selected and autonomous group that usually consists of between 15 and 30 members. Groups are predominantly, though not exclusively, made up of women. Indeed, because women are disproportionately excluded from formal financial institutions, they are actively targeted by savings group programs (Rickard \& Johnsson, 2018). Member contributions are kept in a central "pot," often a physical cashbox that requires three separate keys. These keys are kept by different group members to ensure that opening and closings only occur in the presence of others. Members contribute to and borrow from this pot at each meeting. Interest is charged on the money lent, and the money accumulated through interest is shared among members at pre-defined intervals, usually after 1 year. ${ }^{1}$ Like tiny credit unions, savings groups provide members with highly localized banking services at negligible cost, all while

1 The interest charged is typically low (around 5\%) compared with formal lending institutions (between 18 and $25 \%)$. 
keeping earnings and capital in communities that often struggle to gain access to formal financing. This includes Dar es Salaam, where financial markets are under-developed and interest rates are high. Without formally recognized property rights and often surviving on irregular income flows, many poor people in the city simply lack the required collateral to access formal banking or microcredit institutions (CAHF, n.d.).

International NGOs such as CARE, Plan, Aga Khan, Catholic Relief Services, or Oxfam are routinely catalysts for the formation of savings groups. These provide nascent groups with an organizational template, a cashbox, and a limited period of technical training on group operations through local partners known as "Community-Based Trainers" (CBTs) - though groups may opt to retain their CBTs beyond this period at their own expense. Two savings group models have become particularly well established in Tanzania: the Village Savings and Loans Associations (VSLA) and the Village Community Banks (VICOBA) (Allen \& Panetta, 2010). The present paper focuses on VICOBA, which happened to be more prevalent in the areas we studied. However, group members have significant scope to modify the rules of both VICOBA and VSLA models, making all groups adaptable to local conditions and circumstances. Once established, savings groups are expected to register with the local ward authorities, though many groups opt to remain unregistered.

This highlights the ambiguous relationship that savings groups often have with the state. As informal institutions with rules that are largely created, communicated, and enforced internally, savings groups tend to operate beyond the reach of officially sanctioned channels (Helmke \& Levitsky, 2004). This does not preclude the use of formal elements among groups. Though they require no legal infrastructure to either issue or collect loans, many groups adopt written constitutions outlining the rules on saving and borrowing that have been agreed by members and-depending on whether the group has opted to register with the authorities - stored in the local ward office. Yet these rules are subject to informal evolution over time, often deviating considerably from the original NGO-led savings group template in the process (le Polain et al., 2018; Maliti, 2017). What is clear is that as informal institutions, savings groups are not competing with the state (Helmke \& Levitsky, 2004). Instead, they are commonly providing either a substitutive option for individuals who would otherwise be excluded from formal financial institutions, or a complementary option for those who may have access to formal banking but also enjoy the collective dynamic of savings groups as a motivation for financial discipline (Collins, $2009,114)$. Indeed, rather than see them as poorly regulated and potential threating, both the state and the formal banking sector have tried to court savings groups for a number of reasons, whether to link them to state-backed insurance funds, use them as vehicles for political patronage, or simply to gain access to their capital (Bankable Frontier Associates, 2014; Maliti, 2017; Matthews et al., 2010; Stillman, 2018).

\section{Methodology}

In this paper, we provide new data on the extent of savings group membership and test the hypothesis that they are important for resilience by drawing together survey, interview, and focus group data. We use data from a household survey to measure 
and explore patterns in membership and resilience, combined with qualitative data to explore the processes that link membership to resilience.

Definitions of resilience vary significantly across disciplines, leading to criticisms of conceptual vagueness and the attendant difficulties of measurement (Adger et al., 2011). Moreover, the concept has also come under criticism for being used to absolve state actors of responsibility, or implying that a return to the status quo ex ante is desirable when there may be good reasons for wanting to transform certain systems or structures (Tanner et al., 2017). As Leach (2008, 3) suggests, any discussion of resilience should be prefaced with the query "resilience of what, for whom?" As such, our understanding of resilience has a primarily social and local focus, one centered on the ability of individuals, groups, and institutions to withstand and recover from the impact of shocks and crises, particularly in the context of urban disaster (Adger, 2000, 347). This "bottom-up" emphasis follows from the empirical observation that local communities are key actors in disaster management, often mobilizing and responding to disruption faster than state agencies or governments. This does not imply that states or other actors should not play a critical role in disaster response, nor does it presume that savings groups are a panacea in the field of disaster risk reduction. Though our findings offer grounds for cautious optimism, it is important to note that in certain situations savings groups may conceivably contribute to vulnerability: loans could result in unsustainable debt burdens, activities could instigate conflict between other group members or the broader community, or savings could be lost or stolen. These will be important factors to explore in future research.

The survey data comes from a Disaster-Poverty survey implemented over the course of 2017 and 2018, covering more than 1335 households in Dar es Salaam. It was implemented by the Global Facility for Disaster Reduction and Recovery (GFDRR) partnership and the Poverty Global Practice at the World Bank, under the broader umbrella of the Tanzania Urban Resilience Program (TURP) (for further details, see Erman et al., 2019). Working in collaboration with the Disaster-Poverty survey team, we designed two short questions on membership of mutual aid groups to be included in this survey: (1) "are you, or a member of your household, a member of a savings group or mutual aid group?" and (2) "if yes, does this group help you in the event of flood?" Three limitations to the approach should be kept in mind. First, the type of mutual aid group is unknown, it could be a savings groups (e.g., VICOBA or VSLA) or a rotating credit group (a key difference being that the latter does not charge interest). Second, the survey does not ask whether the household joined the group before or after a flood event. Third, we do not know how many groups the household may belong to.

The survey was sampled to be representative of Dar es Salaam as well as to provide coverage of households specifically living in flood-affected areas. It was implemented over two time periods. In the first, 105 enumeration areas were selected using probability proportional to size (PPS) methods. In each, 10 households were then selected for interviewing. In the second round, 730 households were re-contacted and 419 were re-interviewed, and an additional 282 households were added to the sample. In this analysis, we focus on flood events prior to 2018.

The qualitative data was collected over two rounds of research in November-December 2017 and in May 2019, as part of a broader study into socio-economic characteristics of households living in flood-prone areas undertaken as part 
of the Tanzania Urban Resilience Program. A total of 41 interviews and three focus group discussions were held with residents and local officials. Most were carried out in Swahili with the help of research assistants. Of these, 16 interviews and one focus group were specifically sampled to be members, leaders, and trainers of savings groups. We also analyzed 7 VICOBA constitutions and observed VICOBA training activities. All respondent names have been changed in this report for anonymity.

\section{Group Membership and Experience with Facing Floods}

One-quarter $(24.1 \%)$ of the surveyed households had a member or members in at least one savings group. As shown in Table 1, compared to households without members in savings groups, households with members in savings groups tend to be larger, have more dependents, and are more likely to be connected to local associations. Their heads of household are, on average, a few years older, more likely to be migrants from other regions of Tanzania, less likely to be men, and better educated. They also appear better off as they live in houses that have more sleeping rooms (adjusted for household size) and are more likely to have access to electricity. Our measures for flood risk, however, are not significantly different between groups. Flood-prone areas do not appear more likely to see people join savings groups.

Because many of these socio-economic indicators are collinear, we ran a number of basic linear probability models with the different co-variates. This allows us to test which variables are significantly associated with group membership while controlling for a wide range of household characteristics. As Table 2 shows, many of the differences highlighted earlier do hold: households with members in savings groups are more likely be (1) headed by a woman, (2) wealthier, and (3) connected to a wider social network. The first correlation is likely linked to the long-standing and disproportionate number of women as members of savings groups (Allen \& Panetta, 2010). Similarly, the correlation with wealth is consistent with the fact that savings groups usually charge an entry fee (between 20,000 and 40,000 Tanzania Shillings) and require the ability to be able to save with regularity - typically, weekly or monthly.

The strongest correlation indicated above is between group membership and social network. Members of associations and social groups (that are not defined as savings groups) are $26 \%$ more likely to be members of savings groups. As sociologists have long documented, social capital often creates more social capital; people who are members of one organization are more likely to be a members of other organizations (Bourdieu, 1986). The data does not allow us to make any causal inference. Good social connections certainly help individuals approach (or create) a savings group. However, membership to a savings group may also be a way of introducing members to other groups and social circles. What matters here is to observe that members of savings groups are not only (slightly) better off financially, they are also better connected and therefore potentially better able to tap into a wider support group. In $70 \%$ of the cases, a savings group is only one of several organizations that members belong to. Savings groups do, however, appear to be particularly well placed among community groups to provide support, as we explain in the next section. 
Table 1 Socio-demographic characteristics, depending on whether the household counts one or multiple members who are part of a group

\begin{tabular}{|c|c|c|c|c|c|}
\hline & \multicolumn{2}{|c|}{ Not in group } & \multicolumn{2}{|c|}{ In savings group } & \multirow{2}{*}{$\begin{array}{l}\text { Difference } \\
(t \text { test })^{+}\end{array}$} \\
\hline & Mean & sd & Mean & sd & \\
\hline Size of household & 4.016 & 2.149 & 4.487 & 2.292 & $* * *$ \\
\hline Dependency ratio (children + elderly/adults) & 2.056 & 1.341 & 2.411 & 1.482 & $* *$ \\
\hline Member of association/social group & 0.328 & 0.470 & 0.701 & 0.459 & $* * *$ \\
\hline Has insurance & 0.030 & 0.171 & 0.053 & 0.224 & \\
\hline Benefits from TASAF (social protection) ${ }^{1}$ & 1.973 & 0.163 & 1.970 & 0.170 & \\
\hline Head of household: age & 44.101 & 14.486 & 46.452 & 13.081 & $* *$ \\
\hline Male & 0.742 & 0.438 & 0.671 & 0.471 & $* * *$ \\
\hline No education & 0.057 & 0.232 & 0.020 & 0.139 & $* * *$ \\
\hline Primary education & 0.856 & 0.351 & 0.898 & 0.303 & $*$ \\
\hline Secondary education & 0.067 & 0.250 & 0.072 & 0.260 & \\
\hline Tertiary education & 0.019 & 0.138 & 0.010 & 0.099 & $* * *$ \\
\hline Has always lived in the district & 0.569 & 0.495 & 0.625 & 0.485 & \\
\hline Total years lived in the area & 27.912 & 20.365 & 27.023 & 19.526 & \\
\hline Has moved in from outside Dar es Salaam & 0.181 & 0.386 & 0.171 & 0.377 & \\
\hline Has moved in from Dar es Salaam & 0.775 & 0.418 & 0.707 & 0.456 & $*$ \\
\hline Number of bedrooms & 1.127 & 1.006 & 1.015 & 0.742 & $*$ \\
\hline Number of household items & 2.130 & 1.329 & 2.704 & 1.432 & $* * *$ \\
\hline Simple toilet (pit) & 0.445 & 0.497 & 0.329 & 0.471 & $* * *$ \\
\hline Upgraded latrine (pit) & 0.326 & 0.469 & 0.332 & 0.472 & \\
\hline Sanitized latrine & 0.227 & 0.419 & 0.336 & 0.473 & $* * *$ \\
\hline Access to electricity & 0.830 & 0.376 & 0.908 & 0.290 & $* * *$ \\
\hline Tenant & 0.361 & 0.480 & 0.326 & 0.469 & \\
\hline In area classified as high risk of flood & 0.208 & 0.406 & 0.178 & 0.383 & \\
\hline In area self-described as high risk of flood & 0.230 & 0.421 & 0.276 & 0.448 & \\
\hline In area that has been flooded & 0.247 & 0.432 & 0.234 & 0.424 & \\
\hline
\end{tabular}

The Tanzania Social Action Fund (TASAF) is a government fund whose flagship activities include conditional cash transfer and cash for work programs

${ }^{+} p$ value

$*<0.1$

$* *<0.05$

$* * *<0.01 \mid 1$

\section{Savings Groups and Household Resilience to Flooding in Dar es Salaam}

Interview and focus group respondents indicated that savings groups provide members with access to funds that can help them absorb, cope with, and recover from the impact of flooding. As expected, savings groups help their members save money, but they also provide them with access to extra funds to borrow, known as the "credit fund." Many groups also have a "social fund" (or jamii) which acts as a form of insurance or emergency credit. Both are funded through regular equal contributions. 
Table 2 Linear probability models explaining membership in groups

\begin{tabular}{|c|c|c|}
\hline & Beta & s-error \\
\hline Size of household & 0.004 & $(0.007)$ \\
\hline Dependency ratio (children + elderly/adults) & $0.019 *$ & $(0.009)$ \\
\hline Member of association/social group & $0.264 * * *$ & $(0.024)$ \\
\hline Has insurance & 0.033 & $(0.068)$ \\
\hline Benefits from TASAF & -0.070 & $(0.065)$ \\
\hline Head of household: age & 0.002 & $(0.001)$ \\
\hline Male & $-0.077 * *$ & $(0.027)$ \\
\hline No education & 0.004 & $(0.087)$ \\
\hline Primary education & 0.116 & $(0.080)$ \\
\hline Secondary education & 0.103 & $(0.089)$ \\
\hline Has always lived in the district & 0.053 & $(0.049)$ \\
\hline Total years lived in the area & -0.001 & $(0.001)$ \\
\hline Has moved in from outside Dar es Salaam & -0.062 & $(0.040)$ \\
\hline Has moved in from Dar es Salaam & 0.006 & $(0.038)$ \\
\hline Number of bedrooms & -0.021 & $(0.012)$ \\
\hline Number of household items & $0.025 * *$ & $(0.009)$ \\
\hline Simple toilet (pit) & -0.121 & $(0.191)$ \\
\hline Upgraded latrine (pit) & -0.072 & $(0.191)$ \\
\hline Sanitized latrine & -0.084 & $(0.191)$ \\
\hline Access to electricity & 0.047 & $(0.029)$ \\
\hline Tenant & 0.011 & $(0.026)$ \\
\hline In area classified as high risk of flood & $-0.062^{*}$ & $(0.028)$ \\
\hline In area self-described as high risk of flood & 0.048 & $(0.028)$ \\
\hline In area that has been flooded & 0.001 & $(0.027)$ \\
\hline Constant & 0.100 & $(0.258)$ \\
\hline$N$ & 1330 & \\
\hline$r$-squared & 0.155 & \\
\hline
\end{tabular}

Members decide in advance-and often codify in their group's constitution-what these funds can be used for. Examples include weddings, childbirth, hospitalization, and funerals, all contingencies of life that a range of similar informal insurance mechanisms have commonly covered in Tanzania (De Weerdt et al., 2007).

In theory, groups may be helping households smooth their consumption through savings, loans, or insurance pay-outs associated with membership. Our findings suggest that the latter two sources matter most in helping households cope with the impacts of floods. Savings are generally directed towards predictable annual expenditures. As such, the pay-out cycle of savings groups is typically timed for December or January, between the two rainy seasons, to ensure that money is available for the holidays or for annual payment of school fees. 


\section{The Social Fund}

The social fund can play an important role in helping households manage the risks of flood, but we also find considerable variation in how this fund works. The insurance mechanism is either set in advance and written into the group constitution or decided collectively during a group meeting. In the latter case, there can be more room to extend the coverage of insurance to adverse events that had not been strictly defined ahead of time or in a group's constitution. The "pay-out" can take the form of a zero-interest loan, a pre-defined pay-out amount, or ad hoc contributions from other members. This variation is summarized in Table 3 below.

The social fund often acts as a form of insurance. When written in the group's constitution and taking the form of either a loan or a "pay out" (cases A and B), the fund is regularly augmented by mandatory contributions from members, typically 1000 TSh per week (but at times ranging up to $5000 \mathrm{TSh}$ ). In the event of a welldefined adverse event, such as a death in the family, the claimant can expect either a pay-out or an interest-free loan (usually with a 6-month repayment period). The funds can be accessed almost immediately, and claimants may not have to wait until the next group meeting takes place to receive their compensation.

In some groups, there is no official social fund but ad hoc mandatory contributions that are written into the group constitution (case $\mathrm{C}$ above). As explained by one respondent, Esther, "VICOBA members contribute $2000 \mathrm{TSh}$ as soon as a member or a member's relative is sick." In these cases, as in cases where the pay-outs are not pre-defined, members must convene an emergency meeting or simply contact the group chairperson (e.g., cases D, E, and F in the table above). In some cases, the group's president or other key members may be entitled to make executive emergency decisions. This is the story Hassan told us. In his VICOBA, which gathers school friends from his ward and only meets monthly, it is possible to get a no-interest loan of up to 300,000 TSh for "illness, death and other personal matters" (case D). The whole group normally decides on what these cases may be. However, in case of emergency, the chairperson and executive members can give the loan immediately and announce it to the members at the next meeting.

Regardless of the structure used, the most common type of adverse event "insured" by group membership is the death of a relative (typically, parent, child, or in-law). ${ }^{2}$ In this respect, savings groups may be the institutional evolution of the funeral group-based funeral insurance described as "well placed as models to broaden insurance provision and other developmental activities" (Dercon et al., 2006, 685). Illness and the costs associated with hospitalization or medication are the second most common adverse events insured by savings groups.

Floods and other natural hazards are specifically covered by a limited number of groups. For instance, some savings group constitutions are specified in writing the amount of coverage available for flood-related damages. However, in most cases, such support is ad hoc (case F). Members must appeal to their group in these

\footnotetext{
${ }^{2}$ In the event of a group member's death (whether from a flood or any other event), savings groups usually forgive debts and pass the accrued balance of savings and profits on to the deceased member's stated beneficiary. Debts are typically not passed on to family members. Groups also support family members with non-financial contributions, such as participation in mourning and funeral arrangements.
} 
Table 3 Typology of savings group insurance mechanisms

\begin{tabular}{|c|c|c|c|c|}
\hline & & \multicolumn{3}{|l|}{ Mechanism } \\
\hline & & $\begin{array}{l}\text { No-interest } \\
\text { loan }\end{array}$ & Pay-out & Ad hoc fundraising \\
\hline \multirow{2}{*}{$\begin{array}{l}\text { Definition of adverse life } \\
\text { event (activation of } \\
\text { insurance mechanism) }\end{array}$} & Written in the group constitution & Case A & Case B & Case C \\
\hline & $\begin{array}{l}\text { Discussed and voted by group } \\
\text { members }\end{array}$ & Case D & Case E & Case F \\
\hline
\end{tabular}

circumstances and they are not always successful in doing so. In one instance, a woman explained that her house was severely damaged by flooding, but her group decided not to support her financially, citing their small size and limited resources. The degree to which group members suffer from joint exposure may be a key limitation to savings groups supporting those suffering from floods. After all, a community-based insurance mechanism will not be viable if all community members are affected by the same event (Bhattamishra \& Barrett, 2008).

\section{Credit}

Ultimately, it is access to credit that appears to be the most important source of financing to smooth consumption in the event of a disaster. This is not the original intent of the credit fund in the savings group model, which foresees lending to foster income-generating activity such as a small business investment. Indeed, lending for non-income-generating purposes may be an indication of "entropy," or the gradual deviation from the group's founding rules over time (Maliti, 2017; Matthews et al., 2010). Increased reliance on non-income-generating loans can result in accumulating debt for members, given that loans must be repaid with interest (le Polain et al., 2018). If these debt burdens become unmanageable, this could have a negative impact on the resilience of affected individual members, not to mention the entire group.

Yet if kept within manageable limits, opening up the opportunity to access emergency credit is an important element in mitigating the impact of flooding. In Dar es Salaam, we find that many groups had adapted their rules to allow members to take out loans for non-income-generating activities. Members described using the money accrued through membership in order to move out of flood prone housing into safer accommodation. Community-based trainers demonstrated clear awareness that this was a deviation from the standard savings group model. As one of them explained:

When we started working in the community we saw that things were different, and we started to change what people can do with the money; for example, they can use it to pay rent, as long as they have another source of income or they record an asset - like a cupboard, fridge, radio, or television - that the group can sell if necessary

This adaptation in the rules to allow for the possibility of borrowing against the collateral of possessions such as a cupboard may give households an important 
buffer against selling assets to cope with either short-term costs or lost income in the aftermath of a disaster.

Moreover, we find that members believe that loans, interest, and fines are less likely to be called in if the borrower has been hit by unforeseen event like flood or sickness. Indeed, members often described choosing to renegotiate repayment schedules for members. Such flexibility was routinely highlighted as one of the key advantages of being a savings group member, as opposed to borrowing money via a bank or a mobile application such as M-Pesa. As one respondent, Esther, put it:

I used to get money from the bank, but the bank lacks a sense of humanity. There is no grace period if you are sick or have some other issue. With VICOBA it is different. Your group knows you; they are your neighbours, they understand.

Flexibility is important in situations where life is precarious, such as in flood prone areas of Dar es Salaam. Respondents were not worried about the greater risk of abuse engendered by this more flexible system. Group membership was seen to provide both the opportunity and information to evaluate whether members are sincere and sanction them if necessary. Many stressed that as long as members continued to join regular meetings and participate in key group activities, then repayment periods could be renegotiated. As Grace, a community-based trainer who has trained 80 savings groups, explains:

Sometimes it happens that someone doesn't repay a loan, but the group doesn't chase them out. As long as they continue to attend group meetings and contribute to the group as normal, then the group will come to an agreement about how to repay the money.

NGOs and members of savings groups stress the importance of relatively small group sizes, face-to-face interactions, reciprocal trust, and collective decision-making as central components to their effectiveness. These principles are well represented in the literature on collective action (Olson, 1965; Ostrom, 1990) and social capital (Platteau, 1994; Putnam, 1993; Woolcock \& Narayan, 2000). Or to put it in the language of our respondents, "everyone knows each other," one person explained, "so it is difficult for someone to lie." More research would be needed to identify the exact contours of such trust, but it does appear as a resource that is to some extent durable and accessible, at least slightly more so than in the ethnographic accounts of De Boek (2012) in Kinshasa and the more theoretical accounts of African cities of Simone (2004) that both describe trust and collective action as transient and primarily transactional. While it is clear that the savings groups are transactional in nature, and while regular interaction is described as central (see below), social interactions did not appear "constantly renegotiated" (De Boek, 2012) in savings groups. Rather, savings groups may provide a form of sheltering from such constant re-negotiations.

Of course, groups do sometimes break down, and the supply of trust is not infinite. One respondent highlighted that a former group collapsed when people 
were unable to meet regularly, "people started losing hope and stopped sending money." In other cases, they become too large to operate well. Members reported having a hard time refusing requests from additional people to join their group, and they sometimes reached as many as 50 members. To counter this, trainers explained that once a group reached 30 members, they encouraged the formation of new groups of at least 5 members under the supervision of leaders from the older group. Many groups were also organized in sub-groups of, typically, five individuals. Subgroup members act both as referees and as a close-knit support to each other in times of hardship.

Respondents also described innovations to safeguard the model. Besides fines for payment delays considered unwarranted, many groups explained that they pay community-based trainers or local government officials to act as the collectors of debts from members who stopped attending the group (see Maliti, 2017 for more details). Securing a form of collateral is frequent. In one ward, trainers were recommending that large loans be guaranteed by a relative, arguing that if there is ever an issue, "it will become a matter for the whole family, and they will all come to the office to resolve it." For the same reason, in some areas, groups specified that members needed to have a family house in the area.

These accounts challenge existing ideas about savings groups. Rather than making groups unsustainable, changing practices in lending may reflect adaptation to the highly precarious context of flood prone urban areas. Savings groups have adjusted their institutional structure in ways to ensure that they can scrutinize each other's needs and sanction each-others behavior, should any member abuse the trust of the group. Ultimately, the appeal of savings groups come less from being a source of credit for those who cannot access banks, but rather as a source of financing for those whose incomes are highly vulnerable to shocks and thus consider the strictly defined repayment schedule of formal borrowing to be too risky.

\section{Savings Groups and Community Response to Flooding in Dar es Salaam}

In the survey data analysis, we highlighted that savings groups likely extend social networks. We now turn to the relationship between the social dimension of savings group membership and responses to flooding. The interviews reveal that savings groups often serve to enhance collective action, such as charitable work in response to floods. More generally, they seem to support the idea that members of savings groups could become agents for change to support preventative action against floods.

\section{The Benefits of Savings Group Networks}

Group membership helps people maintain social networks of support under the pressures of urban life. New members are typically close relations to at least one existing member, such as friends, schoolmates, family, work colleagues or people in the 
same trade, or neighbors. In a number of cases, membership criteria pointed to a desire of members to maintain connections that may otherwise become weaker over time (e.g., schoolmates or people who had all lived in the same neighborhood). This may be important because research suggests that weakening social ties and severed networks of mutual aid are sufficiently large — and often overlooked- "costs" to relocating out of precarious or "slum" areas that ultimately may undermine resettlement efforts (Barnhardt et al., 2017). Respondents routinely cited the strong bonds generated by their groups as a key part of what makes participating in savings groups worthwhile.

We also find that members also expand their networks through group participation. Indeed, members also join through acquaintances or other weak ties, which productively extend pre-existing networks of support. One respondent recalled joining her VICOBA through "The sister of my best friend who had asked her whether she knew anyone who wanted to join [a savings group]." She now talks of her previously unknown fellow group members with affection: "We are relatives, we speak one language." This has important implications for resilience. Wider social networks mean that people can draw on more varied sources of support during floods.

Our respondents clearly anticipated the usefulness of such networks. They mentioned groups as good for finding employment opportunities, decent housing, but even more frequently help in times of crisis. Many interviewees recounted how following flood events, they helped other members with food, shelter, or even paid their rent at a temporary location. They all stressed that it was not financially motivated: "We gave it for free" on person said, while others added "We did it out of love" and "If one has problems, you must help each other." Such help is often in the form of cash, but labor, food, and shelter are sometimes also provided. In one case, a group drew upon its social fund to purchase sandbags for a house in danger, but it was the members' voluntary labor to fill and place the bags that was crucial. Similarly, another respondent explained that group members helped during evacuation, alongside with friends, family, and neighbors.

Savings group networks also support resilience through knowledge sharing. Interview respondents routinely emphasized that participation in savings groups helped members develop financial literacy. The chairperson of one group explained that he helped start a VICOBA group for youth so that young people would learn from an early age about concepts related to saving, investment, and the basic actuarial skills of calculating interest. Others emphasized the informal business-related knowledge they received from their groups, covering issues from marketing to entrepreneurship. With regard to floods, participants spoke of the weekly meetings as an opportunity to discuss something they may have heard on the news or the radio, such as weather warnings or flood reports. Group members also reported using mobile messaging services, such as WhatsApp or text messages, to share information about bad weather.

In some contexts, savings groups have been found to engage in collective enterprises that help to mitigate disaster risks, but we found little evidence of this in Dar es Salaam. In Uganda, for example, savings groups collectively purchased solar lamps, because the open flame of older kerosene lamps was deemed an emergency risk (Allen \& Panetta, 2010). In Zimbabwe, Kenya, and Mali, savings groups have 
also invested in joint income generating activities beyond the group's core objectives of lending money (Maliti, 2017). Yet we found that only a limited number of respondents said that their group was actively engaged in collective business ventures. Many said they had heard of groups that ran collectively owned farms or shops, but most of the groups we met did not run a collective enterprise and did not intend to do so. At most, some appeared to pool resources to purchase goods (e.g., soap, batik) wholesale to distribute among members.

\section{Beyond Members' Direct Benefits}

In contrast, we did find widespread evidence that groups often saw charity as a central part of their objectives. Most groups said that their members make small financial and non-financial contributions to charitable activities. These are generally focused on helping members of their local community, though at times they extend into other areas of the city as well. Where the charity activity involved financial contributions, the sums of money contributed are small compared with the savings and loans. For example, where the donation is a one-off annual contribution, members of a group that makes weekly 2000 TSh minimum share contributions described members annually putting 5000 TSh towards charity. In one ward, however, trainers were encouraging groups to set up a separate fund called the "Children's Fund" for dedicated charitable activities, in addition to the standard share and emergency funds. In these cases, contributions were proportionally larger: 500 TSh per week, next to a 2000 TSh minimum share amount. Many also described engaging in non-financial forms of charity. In one case, it was described as a condition of membership that you be "Willing to visit patients in hospital or other similar activities with us." These events may also be actively encouraged by trainers and a means to spread the word about savings groups, as trainers receive financial pay-outs from forming new groups (either in the form of fees or a share of end-of-cycle profits). Some respondents explained that they first heard about VICOBA from a charity event.

Most respondents had examples of groups spontaneously deciding to help in the event of floods. One described how, in 2017, their group had paid to replace stationery and school uniforms washed away by the floods for a number of children in the community. Another explained that last year, they had gone to distribute food in an area outside of their neighborhood that had been badly hit by the flood. This has also been recorded by researchers in Burundi, who note that members of savings groups responded to floods by providing financial assistance to impacted families (Entz et al., 2016, 25).

Membership of savings groups appears to strengthen and expand individual social networks, providing new coping mechanisms during floods. They also constitute a vehicle for engagement in local voluntary activities that benefit the wider community. However, we encountered few instances of groups taking preventative actions to help mitigate risks of flooding in their neighborhoods. For example, one group mentioned that they had collectively engaged in cleaning up a blocked drain in response to financial incentives from the government. Yet, when asked whether 
they would continue cleaning the drain once the incentives had stopped, the group expressed reluctance: "You just know that the rains will come back and we will be badly hit again." Cleaning drains was perceived as only marginally effective in protecting neighborhoods from flood.

\section{Discussion and Conclusions}

Widely hailed as a means to improve access to finance and support entrepreneurialism among unbanked households, savings groups have proliferated across Africa since the early 1990s. In this paper, we argue that savings groups may also play an important role in supporting resilience to floods. Importantly, this effect is not only the result of improved access to funds; it also reflects the role that groups play in sustaining strong social bonds, which means that they can be more flexible in providing finance and may help to overcome key barriers to cooperative action in urban communities. While our research departs from more ethnographic accounts of informal and precarious urban economies and infrastructures (Simone, 2004), we share the idea that at the core of savings groups are the re-assembling and re-configuration of collective action (Chalfin, 2017). What savings groups may provide is a space for collective action that is more successful and stable than other "community building" efforts precisely because it is articulated around "developing the real skills that they need to survive" (Simone, 2004, 420). Membership in savings groups are not driven by vague notions of community building, but rather from clear economic interests.

The savings group model was developed with the expectation that it can improve a household's capacity to save and access loans for business opportunities. In many instances, they also provide some form of insurance against adverse circumstances, such as a death of a relative. Our findings bring more nuance to the debate on the sustainability of savings groups. Such sustainability is typically described as depending on a number of key factors. For one, the interest rate mechanism means that lending should follow a clear business logic motivated by profitable returns; otherwise, there is a risk that households may become overly indebted (le Polain et al., 2018). For another, funds should be directed according to the strength and feasibility of the business case, rather than social ties (Matthews et al., 2010). In addition to this, groups may struggle to "insure" events that many members are simultaneously exposed to (Bhattamishra \& Barrett, 2008). In Dar es Salaam, we find a number of variations in the way that groups function which, on the surface, may threaten group sustainability. Lending rules have been widely adapted to allow for borrowing for non-business-related activities. Repayment schedules are often renegotiated. Groups make ad hoc pay-outs to members in times of need. While there are undoubtedly groups that do collapse, we find that most respondents were very confident about their capacity to scrutinize other members and ensure that people did not abuse the group. This was largely the result of strict rules on attendance at meetings and mutual engagement, backed up by sanctioning through fines and even the use of enforcers.

These results suggest that the group structure can be an effective means to overcome monitoring and sanctioning challenges that often undermine cooperative 
problem solving in urban areas. In these cases, it becomes a form of flexible finance that may be particularly well suited for precarious environments, such as flood prone areas of cities. Indeed, the flexibility of lending that results from membership of savings groups, as well as the speed with which funds can be disbursed, may make them-according to our research participants - a preferable form of finance to more formal channels for low-income and vulnerable households, or even to recent forms of micro-lending through mobile phone companies (such as M-Pesa) that are more creative in dealing with collateral but remain rigid in terms of repayment. In addition to this, the results suggest that the group membership structures may have wider benefits for community resilience. We see a relationship between group membership and size of social networks, and respondents often highlighted this as a benefit of membership. Members express a strong sense of group identity and belonging, and, thanks to their frequent meetings and emphasis on skills, knowledge, and information, savings groups are well-positioned social nodes through which issues related to disaster prevention and response may be communicated.

The flexibility through which savings groups work to increase resilience mean that the "formalization" of these informal institutions may have adverse outcomes. The strength of savings groups has been to develop and adjust to very localized circumstances. While linking groups to formal financial institutions or bringing them under greater oversight and direction from the state may be seen as entailing greater stability, there is a risk that any hardening of informal borrowing and gifting rules may weaken the role that groups play in flood resilience. Similarly, formalization through linking groups to state agencies, as it has been suggested by some during our research, may introduce a vertical dimension into the otherwise horizontal social networks that form the bedrock of saving group structures. As a consequence, trustbased "economies of affection," as Goran Hyden notes, may become increasingly susceptible to clientelism, possibly compromising the sustainability of groups in the process (Hyden, 2005, 89). There is some evidence to date of local political actors in Tanzania seeking to use patronage to savings groups to leverage political influence (Maliti, 2017). Any effort to "scale up" savings groups as a model of improved flood resilience-whether in Tanzania's specific political context or beyond-will need to be attentive to the complex relationships between national elites, local political actors, and savings groups. The risk is that the engineering of savings groups by state or aid actors merely leads to nice-looking but empty shells, with clear rules and connections to state agencies but very little of the adaptiveness and reactivity that is the real strength of savings groups.

Finally, there is significant scope for further research to better understand the relationships between savings groups and resilience. Our results raise at least three potential lines of inquiry. First, more work is necessary to understand what makes savings groups succeed or fail in urban disaster-prone contexts such as Dar es Salaam, and in particular in relationship with their membership. Second, the apparent lack of preventative action among members of savings groups to mitigate the effects of flood is striking. Here, the need is to understand the interplay between savings groups, knowledge about the effectiveness of preventative actions, and the formal mechanisms that the government has established, such as community disaster preparedness and response plans. Finally, more work needs to be done to better 
understand the role of gender in the formation of saving groups, as well as the role savings groups may play in shaping gender roles. Savings groups are predominantly made up of women, a fact that some studies suggest has had a positive impact on female empowerment (Karlan et al., 2017). Yet literature on the gendered impacts of natural disasters consistently highlights how poor women - the same demographic targeted by savings group programs - are both disproportionately affected by disasters and have a more difficult time recovering from them (Enarson et al., 2006; Neumayer \& Plümper, 2007). Understanding the specifically gendered interplay between membership of savings groups and disaster will be an important element of future research.

Author Contribution The authors are listed in reverse alphabetical order. AP and IM carried out preliminary fieldwork. AP, IM, and JBF designed the research project and analyzed the data, with inputs from NK. All authors were involved in the data collection, discussed the results, and contributed to the final manuscript.

Funding Partial financial support was received by the World Bank.

Data Availability All data was collected by the World Bank and is being prepared for public access; enquiries should be directed to aerman@worldbank.org.

Code Availability Stata codes available by request.

\section{Declarations}

Consent to Participate All interview participants in this study provided their informed consent.

Disclaimer This paper is based on research that was, in part, conducted as part of an assessment carried out for the World Bank. The findings, interpretations, and conclusions expressed in this paper are entirely those of the authors. They do not necessarily represent the views of the International Bank for Reconstruction and Development/World Bank and its affiliated organizations, or those of the Executive Directors of the World Bank or the governments they represent.

Conflict of Interest The authors declare no competing interests.

Open Access This article is licensed under a Creative Commons Attribution 4.0 International License, which permits use, sharing, adaptation, distribution and reproduction in any medium or format, as long as you give appropriate credit to the original author(s) and the source, provide a link to the Creative Commons licence, and indicate if changes were made. The images or other third party material in this article are included in the article's Creative Commons licence, unless indicated otherwise in a credit line to the material. If material is not included in the article's Creative Commons licence and your intended use is not permitted by statutory regulation or exceeds the permitted use, you will need to obtain permission directly from the copyright holder. To view a copy of this licence, visit http://creativecommons.org/licen ses/by/4.0\%.

\section{References}

Abrahams, R. (1985). Villages, villagers, and the state in modern Tanzania. Cambridge University Press. Adelekan, I. et al. (2015). Disaster risk and its reduction: An agenda for urban Africa. 37(1). 
Adger, W. N. (2000). Social and Ecological resilience: Are they related? Progress in Human Geography, 24(3), 347-364

Adger, W. N., Brown, K., and Waters, J. (2011). Resilience. In The Oxford Handbook of Climate Change and Society, 696-710.

Allen, H., \& Panetta, D. (2010). Savings groups: What are they?

Anande, D. M., \& Luhunga, P. M. (2019). Assessment of socio-economic impacts of the December 2011 flood event in Dar Es Salaam Tanzania. Atmospheric and Climate Sciences, 09(03), 421-437

Baland, J.-M., and Platteau, J.-P. (2000). Halting degradation of natural resources: Is there a role for rural communities?. Oxford University Press. https://doi.org/10.1093/0198290616.001.0001/acprof-9780198290 612.

Bankable Frontier Associates. (2014). Outcompeting the lockbox - Linking savings groups to the formal financial sector.

Barnhardt, S., Field, E., \& Pande, R. (2017). Moving to opportunity or isolation? Network effects of a randomized housing lottery in urban India. American Economic Journal: Applied Economics, 9(1), 1-32

Beaman, L., Karlan, D., and Thuysbaert, B. (2014). Saving for a (not so) rainy day: A randomized evaluation of savings groups in Mali.

Bhattamishra, R., and Barrett, C. (2008). Community-Based risk management arrangements: An overview and implications for social fund programs.

Bourdieu, P. (1986). The forms of capital. In Handbook of Theory and Research for the Sociology of Education, ed. Richardson, J. Greenwood Press.

CAHF. (n.d.). Housing finance in Tanzania: Overview. Centre for Affordable Housing in Africa Website. http:// housingfinanceafrica.org/countries/tanzania/. (Accessed 17 Oct 2019)

Chalfin, B. (2017). 'Wastelandia': Infrastructure and the commonwealth of waste in urban Ghana. Ethnos, 82(4), 648-671

Collier, P., and Jones, P. (2017). Transforming Dar Es Salaam into a city that works. In Tranzania: The Path to Prosperity, eds. Christopher S. Adam, Paul Collier, and Ndulu Benno, 45-66.

Collins, D. (2009). Portfolios of the Poor: How the world's poor live on $\$ 2$ a day. Princeton University Press.

De Boek, F. (2012). Infrastructure: Commentary from Filip De Boeck. Cultural Anthropology 1-10.

Dercon, S., De Weerdt, J., Bold, T., \& Pankhurst, A. (2006). Group-based funeral insurance in Ethiopia and Tanzania. World Development, 34(4), 685-703

De Weerdt, J., Dercon S., Bold, T., \& Pankhurst, A. (2007). Membership based indigenous insurance associations in Ethiopia and Tanzania. In M. Chen, R. Jhabvala, R. Kanbur, \& C. Richards (Eds.), Membership Based Organizations of the Poor. (pp. 157-176). Routledge.

Dickson, E., Baker, J. L., Hoornweg, D., and Asmita, T. (2012). Urban Risk assessments Urban Risk Assessments.

Elias-Trostmann, K., Cassel, D., Burke, L., and Rangwala, L. (2018). World Resource Institute Working Paper Stronger than the storm: Applying the urban community resilience assessment to extreme climate events.

Ellickson, R. C. (1991). Order without law: How neighbors settle disputes. Harvard University Press.

Enarson, E., Fothergill, A., \& Peek, L. (2006). Gender and disaster: Foundations and directions. In H. Rodriguez, E. L. Quarantelli, \& R. Dynes (Eds.), Handbook of Disaster Research. (pp. 130-146). Springer.

Entz, M., Karsgaard, J., and Salomons, M. (2016). An overview of savings and self-help groups, their contributions to improved food security, and how to improve their function. https://www.prismaweb.org/nl/wpcontent/uploads/2017/07/An-Overview-of-Savings-and-Self-Help-Groups-Their-Contributions-to-Impro ved-Food-Security-and-How-to-Improve-their-Function | Entz-Karsgaard-Salomons | November-2016. pdf.

Erman, A., et al. (2019). Wading out the storm: The role of poverty in exposure, vulnerability, and resilience to floods in Dar Es Salaam.

Fafchamps, M. (1992). Solidarity networks in preindustrial societies: Rational peasants with a moral economy. Economic Development and Cultural Change, 19(9), 155-179

Gash, M., and Odell, K. (2013). The evidence-based story of savings groups: A synthesis of seven randomized control trials.

Global Disaster Preparedness Center. (2019). Designing solutions for urban community resilience.

Gupte, J. (2019). ESRC-DFID research for policy and practice: Urban community resilience. (March): 1-6.

Helmke, G., \& Levitsky, S. (2004). Informal institutions and comparative politics: A research agenda. Perspectives on Politics, 2(04), 725

Hyden, G. (1980). Beyond Ujamma in Tanzania: Under-development and an uncaptured peasantry. Heinemann.

Hyden, G. (2005). African Politics in Comparative Perspective. Cambridge University Press. 
IPCC. (2012). Managing the risks of extreme events and disasters to advance climate change adaptation: A special report of working groups I and II of the Intergovernmental Panel on Climate Change. Cambridge University Press.

Jahns, E. (2014). Savings Groups, shocks and coping strategies: The case of poor rural households in El Salvador. Tufts University.

Karlan, D., Savonitto, B., Thuysbaert, B., \& Udry, C. (2017). Impact of Savings groups on the lives of the poor. Proceedings of the National Academy of Sciences of the United States of America, 114(12), 3079-3084

Leach, M. (2008). Re-framing resilience: A symposium report.

le Polain, M., Sterck, O., \& Nyssens, M. (2018). Interest rates in savings groups: Thrift or threat? World Development, 101, 162-172

Maghimbi, S. (1995). The conflict between the state and grassroots-based institutions in Tanzania's rural development. In The Tanzanian Peasantry: Further Studies, eds. P. Forster and S. Maghimbi. Avebury.

Maghimbi, S. (2010). Cooperatives in Mainland Tanzania: Revival and Growth. Dar es Salaam.

Maliti, E. (2017). Deviation of community savings groups from their apparent methodology. International Journal of Social Economics, 44(3), 326-336

Manyena, S. B. (2006). The concept of resilience revisited. Disasters 30(4): 434-50. https://doi.org/10. 1111/j.0361-3666.2006.00331.x (March 18, 2020).

Matthews, B., Musoke, C., and Green, C. (2010). Group savings and loans associations impact study.

Neumayer, E., \& Plümper, T. (2007). The gendered nature of natural disasters: The impact of catastrophic events on the gender gap in life expectancy, 1981-2002. Annals of the Association of American Geographer, 97(3), 551-566

Odera, G., and Muruka, G. (2007). Savings and internal lending communities (SILC) in Kenya.

Olson, M. (1965). The logic of collective action. Harvard University Press.

Ostrom, E. (1990). Governing the commons. Cambridge University Press.

Ostrom, E. (2005). Understanding the Diversity of Structured Human Interactions. Understanding Institutional Diversity. (pp. 3-31). Princeton University Press.

Panman, A., and Lozano-Gracia, N. (2021). Policy Research Working Paper Making room for renters: Understanding and supporting rental markets in the Global South - Evidence from Dar Es Salaam, Tanzania. https://documents.worldbank.org/en/publication/documents-reports/documentdetail/ 235901615576569696/making-room-for-renters-understanding-and-supporting-rental-markets-inthe-global-south-evidence-from-dar-es-salaam-tanzania.

Platteau, J.-P. (1994). Behind the market stage where real societies exist. Journal of Development Studies, 30, 533-577

Putnam, R. (1993). Making democracy work: Civic traditions in modern Italy. Princeton University Press. Rickard, K., and Johnsson, A. (2018). Women's empowerment and savings groups: What do we know?

Rodima-Taylor, D. (2012). Passageways of Cooperation: Mutual help in post-socialist Tanzania.

Ruel, M. (1959). The social organization of the Kuria: A fieldwork report. Cambridge University Press.

Simon, D. (2010). UNU-WIDER Working PaperWorking Paper The challenges of global environmental change for urban Africa.

Simone, A. (2004). People as infrastructure: Intersecting fragments in Johannesburg. Public Culture, 16(3), 407-429

Smith, W., \& Scott, L. (2015). and Andrew Shepherd. Financial inclusion policy guide.

Stillman, S. (2018). Linking informal savings groups to a formal financial institution: The experience of Mwnaga Community Bank in Tanzania.

Tanner, T., Bahadur, A., \& Moench, M. (2017). Challenges for resilience policy and practice.

Woolcock, M., \& Narayan, D. (2000). Social capital: Implications for development theory, research, and policy. The World Bank Research Observer, 15(2), 25-49

World Bank. (2009). Systems of cities: Harnessing urbanization for growth and poverty alleviation.

Publisher's Note Springer Nature remains neutral with regard to jurisdictional claims in published maps and institutional affiliations. 


\section{Authors and Affiliations}

\section{Alexandra Panman ${ }^{1}$ - Ian Madison ${ }^{2}$ - Nyambiri Nanai Kimacha ${ }^{3}$. Jean-Benoît Falisse ${ }^{4}$}

Ian Madison

i.madison@1se.ac.uk

Nyambiri Nanai Kimacha

nkimacha@worldbank.org

Jean-Benoît Falisse

jb.falisse@ed.ac.uk

1 University College London, London, UK

2 London School of Economics, London, UK

3 World Bank, Washington, D.C., USA

4 Edinburgh University, Edinburgh, Scotland 